\title{
The relationship between polymorphism of the CXCR1 gene and the risk of endometritis in Holstein dairy cows
}

\author{
Reza Asadpour ${ }^{1 *}$, Logman Feyzi ${ }^{1}$, Razi Jafari-Joozani ${ }^{1}$, Hossain Hamali ${ }^{1}$, \\ Abolfazl Hajibemani ${ }^{1}$, and Masoumeh Firouzamandi ${ }^{2}$ \\ ${ }^{1}$ Department of Clinical Sciences, Faculty of Veterinary Medicine, University of Tabriz, Tabriz, Iran \\ ${ }^{2}$ Departments of Pathobiology, Faculty of Veterinary Medicine, University of Tabriz, Tabriz, Iran
}

\begin{abstract}
ASADPOUR, R., L. FEYZI, R. JAFARI- JOOZANI, H. HAMALI, A. HAJIBEMANI, M. FIROUZAMANDI: The relationship between polymorphism of the CXCR1 gene and the risk of endometritis in Holstein dairy cows. Vet. arhiv 90, 557-563, 2020.
\end{abstract}

\section{ABSTRACT}

Endometritis is one of the reproductive diseases that can cause disturbances of postpartum uterine health in cattle. Therefore, identification of resistant genotypes to endometritis is essential. The objective of this study was to evaluate the association between the single nucleotide polymorphism in the interleukin- 8 receptor- $\alpha$ (CXCR1) gene and the possibility of endometritis in Holstein dairy cows. For this purpose, blood samples were collected from multiparous dairy cows with a history of clinical endometritis $(n=30)$, and normal, healthy cows as the control group $(\mathrm{n}=10)$. Deoxyribonucleic acid (DNA) was isolated from a blood sample. To determine genotype, the polymerase chain reaction-restriction fragment length polymorphism technique (PCR-RFLP) was used. The results indicated the presence of a different proportion of polymorphisms $(\mathrm{G}>\mathrm{C})$ in the CXCR1 gene in cows with clinical endometritis, compared to the control group. Statistical analyses showed that there is a significant correlation between the incidence of the disease and the CXCR1 genotype in nucleotide position 956. The incidence rate of clinical endometritis was associated with the CXCR1.956 genotype; cows with genotype GC had a higher incidence of clinical endometritis compared with cows with the GG genotype. Overall, the results showed that CXCR1 polymorphism could be a useful marker for identification of resistant genotypes to endometritis in Holstein dairy cows.

Key words: polymorphism; CXCR1; endometritis; dairy cow

\section{Introduction}

Uterine infection is a significant disease affecting the economic efficiency of dairy herds, and causing infertility (LEBLANC et al., 2002; SHELDON and DOBSON, 2004; GILBERT et al., 2005). The outcome of uterine infection depends on the number and virulence of the organisms present, (COHEN et al., 1995), as well as the condition of the uterus and its inherent defence mechanism (HUSSAIN 1989). The innate immune system functions as the first line of defence during uterine infection, and therefore plays a vital role in the early recognition and elimination of invading microorganisms (DHALIWAL et al., 2001; SHELDON et al.,

\footnotetext{
*Corresponding author:

Reza Asadpour, Department of Clinical Science, Faculty of Veterinary Medicine, University of Tabriz, P.O. Box 51666-16471, Iran, E-mail: rasadpour4@gmail.com
} 
2009). The use of immune markers is valuable to reduce uterine infections in the body.

Interleukin 8 (IL-8) is the most critical chemo-attractant for neutrophils, binding IL-8 to its receptors (CXCR1 and CXCR2) on the neutrophil cytoplasmic membrane, influencing neutrophil activation, stimulating chemotaxis, and enhancing the phagocytosis and killing ability of this cell (MITCHEL et al., 2003). The CXCR1 gene encodes one of the two receptors present on polymorphonuclear leukocytes (PMNL) for IL8, known as chemokine (C-X-C motif) receptor 1 (CXCR1). The IL8-CXCR1 receptor-ligand complex is responsible for several vital immune responses, which include neutrophil migration, increased host cell survival, and the modification of cytokine profiles (KETTRITZ et al., 1998; LAHOUASS et al., 2008; MITCHELL et al., 2003). There is stable in vitro evidence that polymorphism in CXCR1 such as c.735C $>\mathrm{G}$ (dbSNP ID: rs208795699) affects the survival and migration of bovine blood PMNL in response to IL-8 (PIGHETTI et al., 2012). The CXCR1 c.777C $>$ G has been investigated in relation to reproduction diseases, but to date, no significant association has been found (KOŚCIUCZUK et al., 2014).

CXCR1 has been associated with somatic cell count, milk yield, subclinical and clinical mastitis (KORMANN et al., 2012; LAHOUASSA et al., 2008). Therefore, this gene is suggested as a potential candidate marker for infection (KETTRITZ et al., 1998). The level of IL8 is connected in the literature with reproduction disorders. Therefore, an examination of its receptor with respect to reproduction traits could bring new results. The present study aimed to investigate the association between CXCR1 gene polymorphism, and postpartum endometritis in dairy cattle.

\section{Materials and methods}

Animal. This study was carried out on registered multiparous Iranian Holstein cows at the farm of the Azarnegin milk and meat producing complex in Tabriz, East Azerbaijan province, North Western Iran. Two Hundred postpartum dairy cows were examined once between 18 and 38 days after birth.
Forty cows were allocated into two groups: cows with a history of clinical endometritis $(n=30)$ and cows without a history of endometritis $(n=10)$. All cows were on the same farm and under the same management conditions, with the lactation number ranging from 3 to 8 . Cattle were hygienically calved in calving boxes and kept in single boxes for at least 10 days after delivery. The ration used for nutrition was a combination of corn silage, alfalfa hay, and concentrates.

Clinical examination. The cows were examined at 18 to 38 DIM for clinical endometritis. After inspection for the presence of fresh discharge around the vulva, perineum or tail, if no discharge was noticeable externally, a vaginal examination was performed. After cleaning the cow's vulva with a dry paper towel, a clean, lubricated and gloved hand was inserted through the vulva. By palpation in all directions in the vagina, the mucous contents of the vagina were withdrawn manually for examination. In relation to the colour and proportion of pus in the mucus, the vaginal discharge was scored on a scale of 0-3 (SHELDON et al., 2006; WILLIAMS et al., 2005), $0=$ normal uterine discharge, $1=$ flakes of purulent exudates in the uterine discharge, $2=>50 \%$ of the uterine discharge is made up of purulent exudates and $3=$ haemorrhagic uterine discharge mixed with purulent exudates (SHELDON et al., 2006; WILLIAMS et al., 2005). In all cows (normal and clinical endometritis), ultrasonographic scanning was performed using a $5 \mathrm{MHz}$ rectal linear probe (Easyscan, BCF, UK) to assess ovarian structures, the diameter of the uterus, echo texture, the thickness of the uterine wall and intraluminal fluid accumulation.

DNA extraction and Polymerase Chain Reaction-restriction fragment length polymorphism (PCR-RFLP). Whole blood (10 mL per cow) was collected from the coccygeal vein into vacutainer tubes with EDTA (Becton Dickinson, Franklin Lakes, NJ, USA), and stored at $-20{ }^{\circ} \mathrm{C}$ for subsequent DNA extraction. DNA from the blood samples was extracted using a DNeasy Blood \& Tissue Kit (Qiagen, Germantown, MD, USA), following the manufacturer's instructions. The concentration and purity of the extracted DNA was 
verified optically by a ND-1000 spectrophotometer (Nanodrop Technology, Wilmington, DL, USA).

PCR was carried out on the extracted genomic DNA for amplification of the CXCR1 gene (NCBI Gen Bank number: HM013954.2). Sequences of specific primers used were obtained from a previous study (SZEBENI et al., 2006). PCR amplification reaction was performed in $25 \mu \mathrm{L}$ total volume reaction containing: $12.5 \mu \mathrm{L}$ of Taq DNA Polymerase 2x Master Mix RED (Ampliqon A/S, Stenhuggervej 22, DK-5230 Odense M, Denmark), 10 pmol of each primer CXCR1 (Forward: 5'-CTTCATCTTCCGGTGAGGCCTATCAAC-3'; reverse:

5'-AAGGGAAGGGGACTTTCCTGGCTG-3'), $100 \mathrm{ng}$ of each genomic DNA as template and $\mathrm{dH}_{2} \mathrm{O}$. The PCR programme was as follows: an initial denaturation at $94{ }^{\circ} \mathrm{C}$ for 2 minutes, followed by 40 cycles of $94^{\circ} \mathrm{C}$ denaturation for 15 seconds, $62{ }^{\circ} \mathrm{C}$ annealing for 20 seconds, $72{ }^{\circ} \mathrm{C}$ extension for 60 seconds. After the last cycle, a 10 minute final extension step at $72{ }^{\circ} \mathrm{C}$ was added. Template-free water was used as a negative control.

Restriction fragment length polymorphism (RFLP). $4 \mu \mathrm{L}$ of amplified PCR products were subject to restriction enzyme digestion reaction by 1 unit of Hinf1 (5'-G $\downarrow$ ANT- 3') restriction endonucleases according to the manufacturer's instructions (Thermo Fisher Scientific, Waltham, MA, USA). The digested DNA fragments were run on $2 \%$ agarose gel, and then, for better differentiation, RFLP products were run on $7 \%$ polyacrylamide gel. RFLP products were confirmed by $7 \%$ polyacrylamide gel electrophoresis containing TBE $1 \mathrm{x}$ buffer at room temperature (10$\left.20^{\circ} \mathrm{C}\right)$, and constant $8 \mathrm{~W}(120 \mathrm{~V})$ for $6-7 \mathrm{~h}$. Before loading, $3 \mu \mathrm{L}$ of PCR product was mixed with $6 \mu \mathrm{L}$ of SSCP loading dye $(95 \%$ deionized formamide and 5\% DNA Loading Dye 6x], denatured for 10 min at $95{ }^{\circ} \mathrm{C}$, and snap cooled. SSCP bands were visualized after staining by a fast and sensitive silver method (BASSAM et al., 1991).

Statistical analyses. The Pearson $\chi^{2}$ test was used to compare genotype distributions between clinical endometritis and control cows. Statistical modelling using logistic regression was used to calculate the relative risk (odds ratio - OR) of genotypes for a case-control study. Odds ratios were expressed together with a $95 \%$ confidence interval. The relationships between different polymorphisms and infections were only analysed for the mutation $+956 \mathrm{C}>\mathrm{G}$. Group II (cows with no history of uterine infections), was assumed to be the control, and results were considered statistically significant at $\mathrm{P} \leq 0.05$.

\section{Results}

The targeted part of the CXCR1 gene was successfully amplified as a 311 bp fragment on $2 \%$ agarose gel (Fig.1). Based on the Hinfl enzyme digestion pattern, two different alleles were considered. In 11 animals out of 40 there was only one restriction site corresponding to two RFLP fragments with a size of $161 \mathrm{bp}$ and $150 \mathrm{bp}$, in stark contrast to 29 out of 40 animals, enzyme digestion showed three distinct RFLP fragments corresponding to $147 \mathrm{pb}, 150 \mathrm{bp}$ and $50 \mathrm{bp}$ (Fig. $2 \& 3)$. Genotypic and allelic distribution for the G956C polymorphisms are shown in Table 1.

The results of our study demonstrate the existence of polymorphism within CXCR1 G956C in the endometritis group. Dairy cows with and without clinical endometritis were compared from the point of view of the presence of polymorphism within the CXCR1 G956C gene. The genotype frequencies of the GC compared to GG for the CXCR1 G956C polymorphism in dairy cows with endometritis were significantly different from those in the control group $(\mathrm{P}<0.001)$. There were significant differences between the dairy cows with endometritis and the control group regarding the GG genotype frequencies, compared with GG and GC for the CXCR1 G956C polymorphism $(\mathrm{P}<0.0001)$. There was a statistically significant difference between the $\mathrm{C}$ allele frequencies of dairy cows with endometritis and the control group for the CXCR1 G956C polymorphism $(\mathrm{P}<0.0001)$. Overall, a significant association was observed in two genetic models when all mutations were pooled together $(\mathrm{C}$ versus $\mathrm{G}, \mathrm{GC}$ versus $\mathrm{GG}$ and $\mathrm{GC}+\mathrm{CC}$ versus $\mathrm{GG})$ (Table 1). 
Table 1. Allele and genotype frequencies for CXCR1 G956C in the cows suffered bovine endometritis and control group

\begin{tabular}{|c|c|c|c|c|c|}
\hline & \multicolumn{2}{|c|}{ Allele's frequencies, n (\%) } & \multicolumn{3}{|c|}{ Mutation type n (\%) } \\
\hline & $\mathrm{G}$ allele & $\mathrm{C}$ allele & GG & GC & $\mathrm{CC}$ \\
\hline Uterine infection $(\mathrm{n}=30)$ & $31(51.6)$ & $29(48.4)$ & $1(3.3)$ & $29(96.7)$ & $0(0)$ \\
\hline Controls $(n=10)$ & $20(100)$ & $0(0)$ & $10(100)$ & $0(0)$ & $0(0)$ \\
\hline Total (40) & $51(63.75)$ & $29(36.25)$ & $11(27.5)$ & $29(72.5)$ & $0(0)$ \\
\hline $\mathrm{C}$ versus $\mathrm{G}$ & $\mathrm{P}_{\text {value }}<0.0001$ & & & & \\
\hline GC versus GG & $\overline{\mathrm{P}}_{\text {value }}<0.0001$ & & & & \\
\hline $\mathrm{GC} / \mathrm{CC}$ versus $\mathrm{GG}$ & $\mathrm{P}_{\text {value }}<0.0001$ & & & & \\
\hline
\end{tabular}

Genotypes distribution and allele frequencies in both groups were evaluated using chi-square test

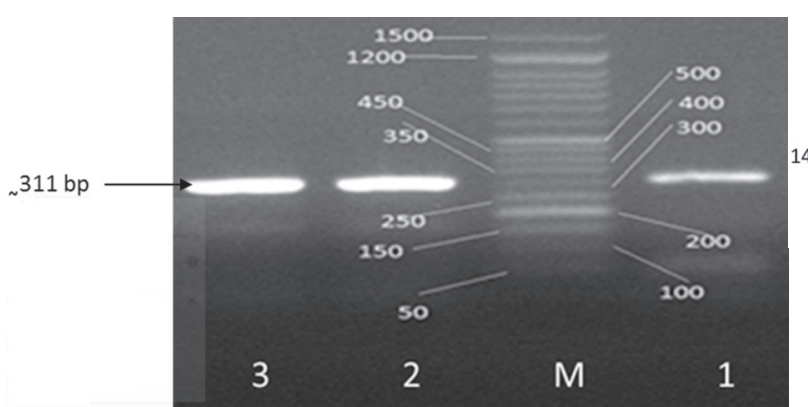

Fig. 1. Electrophoresis of PCR products of the CXCR1 gene on $2 \%$ agarose gel. M: DNA marker $50 \mathrm{bp}$

(Cinnagen co, Iran). Lanes 1-3: Amplified PCR product by specific primer resulted in a $311 \mathrm{bp}$ fragment.

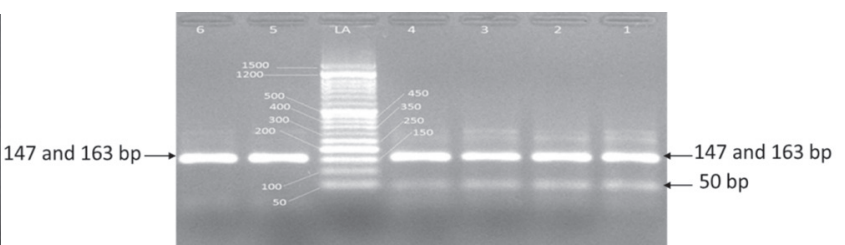

Fig. 2. RFLP fragments of the CXCR1 gene after digestion with Hinf1 enzyme on 2\% agarose gel. LA: DNA Ladder 50 bp (Cinnagen co, Iran); Lanes 1-4: RFPL fragments (with three distinct fragments) in the infected animals with clinical endometritis (heterozygote type as a GC genotype). Lanes 5-6: RFPL fragments in the healthy animals with the GG genotype.

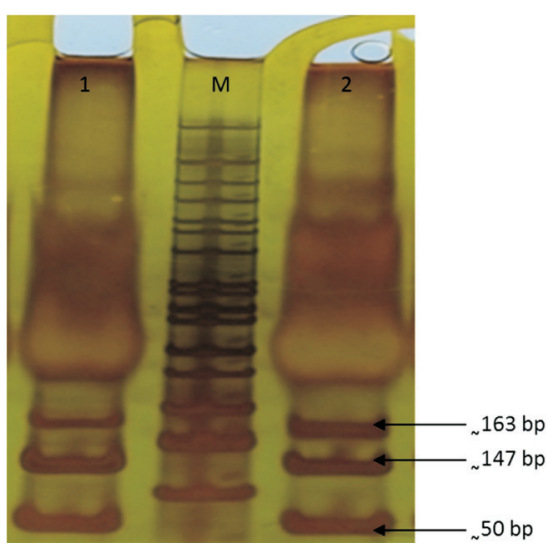

Fig. 3. RFLP fragments in the CXCR1 gene after digestion with Hinf1 enzyme on 7\% polyacrylamide gel. M: DNA Ladder, 50-1500 bp (Cinnagen co, Iran); Lanes 1and 2: RFPL fragments in the infected animals with clinical endometritis (heterozygote type). 


\section{Discussion}

Interleukin 8 levels have been associated with several reproduction diseases, e.g., endometritis ( JECMINKOVA et al., 2018). Consequently, we determined to examine the association of clinical endometritis and its receptor (CXCR1 gene) polymorphism. The results of this study showed that there is a significant relationship between the presence of polymorphism in the immunogenic gene and endometritis in Holstein dairy cows. A previous study reported the coexistence of CXCR1c.735 $\mathrm{C}>\mathrm{G}$ polymorphism and the incidence of the uterine diseases (metritis and endometritis), but did not find any significant association (GALVÃO et al., 2011). Our findings showed the incidence rate of clinical endometritis was associated with the CXCR1.956 genotype; cows with genotype GC had a higher incidence rate of clinical endometritis compared with GG cows. Some previous studies describe the positive effect of the $\mathrm{G}$ allele in GG genotypes on resistance to clinical mastitis (BAGHERI et al., 2016). Conversely, earlier studies showed that cows with genotype GG had an increased incidence rate of clinical mastitis, and a decreased fertility rate (VERBEKE et al., 2012; GALVÃO et al., 2010; PRYCE et al., 2004 ).

Therefore, it seems that polymorphisms in different regions of the CXCR1 gene cause interruptions in the ability of IL- 8 to bind to its receptor (CXCR1), which may lead to interference with the potential of IL- 8 to activate neutrophils and neutrophil migration to the position of the infection, and consequently a higher incidence of reproductive diseases (RAMBEAUD and PIGHETTI 2005; 2007).

\section{Conclusions}

The results of this study also provide evidence that some polymorphisms of the CXCR1 gene are functional mutations, and variations in them probably create an immunological mechanism for sensitization to uterine infection in dairy cattle. Therefore, it can be concluded that cows that have mutations in the region of the interleukin- 8 receptor gene (CXCR1) are sensitive to clinical endometritis. Overall, the results showed that CXCR1 polymorphism could be a useful marker for identification of resistant genotypes to clinical endometritis.

\section{Conflict of interest}

The author(s) declare no potential conflicts of interest to the research, authorship, and/or publication of this article.

\section{Acknowledgements}

This study was financially supported by the University of Tabriz. The authors thank the Azarnegin Company (Tabriz, Iran) for their permission to use their herd in the experiment.

\section{References}

BAGHERI, M., M. MORADI-SHARHRBABAK, R. MIRAIE-ASHTIANI M. SAFDARI-SHAHROUDI R. ABDOLLAHI-ARPANAHI (2016): Case-control approach application for finding a relationship between candidate genes and clinical mastitis in Holstein dairy cattle. J. Appl. Genet. 57, 107-112.

DOI: $10.1007 / \mathrm{s} 13353-015-0299-0$.

BASSAM, B. J., G. CAETANO-ANOLLÉS, P. M. GRESSHOFF (1991): Fast and sensitive silver staining of DNA in polyacrylamide gels. Anal. Biochem. 196, 80-83. DOI: 10.1016/0003-2697(91)90120-i

COHEN, R. O., M. BERNSTEIN, G. ZIV (1995): Isolation and antimicrobial susceptibility of Actinomyces pyogenes recovered from the uterus of dairy with retained fetal membranes and postparturent endometritis. Theriogenology 43, 1389-1397.

DOI: 10.1016/0093-691X(95)00124-Q

DHALIWAL, G. S., R. D. MURRAY, Z. WOLDEHIWET (2001): Some aspects of immunology of the bovine uterus related to treatments for endometritis. Anim. Reprod. Sci. 67, 135-152.

DOI: 10.1016/S0378-4320(01)00124-5 -152

GALVÃO, K., M. FLAMINIO, S. BRITTIN, R. SPER, M. FRAGA, L. CAIXETA, A. RICCI, C. GUARD, W. BUTLER, R. GILBERT (2010): Association between uterine disease and indicators of neutrophil and systemic energy status in lactating Holstein cows. J. Dairy Sci. 93, 2926-2937.

DOI: $10.3168 /$ jds.2009-2551

GAlVÃO, K., G. PIGHETTI, S. CHEONG, D. NYDAM, R. GILBERT (2011): Association between interleukin-8 receptor- $\alpha$ (CXCR1) polymorphism and disease incidence, production, reproduction, and survival in Holstein cows. J. Dairy Sci. 94, 2083-2091.

DOI: $10.3168 /$ jds.2010-3636

GILBERT, R. O., S. T. SHIN, C. L. GUARD, H. N. ERB, M. FRAJBLAT (2005): Prevalence of endometritis and its effects on reproductive performance of dairy cows. Theriogenology 64, 1879-1888.

DOI: 10.1016/j.theriogenology.2005.04.022

HUSSAIN, A. M. (1989): Bovine uterine defense mechanisms: A review. J. Vet. Med. 36, 641-651. 
JECMINKOVA, K., U. MULLER, J. KYSELOVA, Z. SZTANKOOVA, L. ZAVADILOVA, M. STIPKOVA, I. MAJZLIK (2018): Association of leptin, toll-like receptor 4 , and chemokine receptor of interleukin $8 \mathrm{CXC}$ motif single nucleotide polymorphisms with fertility traits in Czech Fleckvieh cattle. Asian Australas. J. Anim. Sci. 31, 1721-1728.

DOI: 10.5713 /ajas. 17.0900

KETTRITZ, R., M. L. GAIDO, H. HALLER, F. C. LUFT, C. J. JENNETTE, R. J. FALK (1998): Interleukin-8 delays spontaneous and tumor necrosis factor- $\alpha$-mediated apoptosis of human neutrophils. Kidney Int. 53, 84-91.

DOI: 10.1046/j.1523-1755.1998.00741.x

KORMANN, M. S., A. HECTOR, V. MARCOS, L. E. MAYS, M. KAPPLER, T. ILLIG, N. KLOPP, S. ZEILINGER, M. CAREVIC, N. RIEBER (2012): CXCR1 and CXCR2 haplotypes synergistically modulate cystic fibrosis lung disease. Eur. Respir. J. 39, 1385-1390.

DOI: $10.1183 / 09031936.00130011$

KOŚCIUCZUK, E. M., P. LISOWSKI, J. JARCZAK, J. KRZYŻEWSKI L. ZWIERZCHOWSKI, E. BAGNICKA (2014): Expression patterns of $\beta$-defensin and cathelicidin genes in parenchyma of bovine mammary gland infected with coagulase-positive or coagulase-negative Staphylococci. BMC. Vet. Res. 10,1.

DOI: 10.1186/s12917-014-0246-Z

LAHOUASSA, H., P. RAINARD, A. CARATY, C. RIOLLET (2008): Identification and characterization of a new interleukin- 8 receptor in bovine species. Mol. Immunol. $45,1153-1164$.

DOI: 10.1016/j.molimm.2007.07.011

LEBLANC, S. J., T. F. DUFFIELD, K. E. LESLIE, K. G. BATEMAN, G. P. KEEFE, J. S. WALTON, W. H. JOHNSON (2002): Defining and diagnosing postpartum clinical endometritis and its impact on reproductive performance in dairy cows. J. Dairy Sci. 85, 2223-2236.

DOI: $10.3168 /$ jds.S0022-0302(02)74302-6

MITCHELL G. B., B. N. ALBRIGHT, J. L. CASWELL (2003): Effect of interleukin-8 and granulocyte colony-stimulating factor on priming and activation of bovine neutrophils. Infect. Immun. 71, 1643-1649.

DOI: 10.1128/iai.71.4.1643-1649.2003

PIGHETTI G. M., C. J. KOJIMA, L. WOJAKIEWICZ, M. RAMBEAUD (2012): The bovine CXCR1 gene is highly polymorphic. Vet. Immunol. Immunopathol. 145, 464-470. DOI: $10.1016 /$ j.vetimm.2011.09.012

PRYCE, J. E., M. D. ROYAL, P. C. GARNSWORTHY, I. L. MAO (2004): Fertility in the high-producing dairy cow. Livest. Prod. Sci. 86, 125-135.

DOI: $10.1016 / \mathrm{S} 0301-6226(03) 00145-3$
RAMBEAUD, M., G. PIGHETTI (2005): Impaired neutrophil migration associated with specific bovine CXCR2 genotypes. Infect. Immun.73, 4955-4959.

DOI: 10.1128/IAI.73.8.4955-4959.2005

RAMBEAUD, M., G. PIGHETTI (2007): Differential calcium signaling in dairy cows with specific CXCR1 genotypes potentially related to interleukin- 8 receptor functionality. Immunogenetics. 59, 53-58.

DOI: $10.1007 / \mathrm{s} 00251-006-0170-\mathrm{x}$

SHELDON, I. M., G. S. LEWIS, S. LEBLANC, R. O. GILBERT (2006): Defining postpartum uterine disease in cattle. Theriogenology 65, 1516-1530.

DOI: 10.1016/j.theriogenology.2005.08.021

SHELDON I. M., J. CRONIN, L., G. GOETZE, H. J. DONOFRIO SCHUBERTH (2009): Defining postpartum uterine disease and the mechanisms of infection and immunity in the female reproductive tract in cattle. Biol. Reprod. 81, 1025-1032.

DOI: 10.1095/biolreprod.109.077370

SHELDON, I., H. DOBSON (2004): Postpartum uterine health in cattle. Anim.Rep. Sci. 82, 295-306.

DOI: 10.1016/j.anireprosci.2004.04.006

SZEBENI B., R. SZEKERES, K. RUSAI, Á. VANNAY, G. VERES, A. TRESZL, A. ARATÓ, T. TULASSAY B. VáSáRHELYI (2006): Genetic polymorphisms of CD14, toll-like receptor 4 , and caspase-recruitment domain 15 are not associated with necrotizing enterocolitis in very low birth weight infants. J. Pediatr. Gastroenterol. Nutr. 42, 2731.

DOI: 10.1097/01.mpg.0000192246.47959.b2

VERBEKE, J., S. PIEPERS, L. PEELMAN, M. VAN POUCKE, S. DE VLIEGHER (2012): Pathogen-group specific association between CXCR1 polymorphisms and subclinical mastitis in dairy heifers. J. Dairy. Res. 79, 341351.

DOI: $10.1017 / \mathrm{S} 0022029912000349$

WILLIAMS, E. J., D. P. FISCHER, D. U. PFEIFFER, G.C. ENGLAND, D.E. NOAKES, H. DOBSON, I.M. SHELDON (2005): Clinical evaluation of postpartum vaginal mucus reflects uterine bacterial infection and the immune response in cattle. Theriogenology 63, 102-117.

DOI: 10.1016/j.theriogenology.2004.03.017 
R. Asadpour et al.: The relationship between polymorphism of the CXCR1 gene and the risk of endometritis in Holstein dairy cows

Received: 7 September 2019

Accepted: 17 March 2020

\begin{abstract}
ASADPOUR, R., L. FEYZI, R. JAFARI -JOOZANI, H. HAMALI, A. HAJIBEMANI, M. FIROUZAMANDI: Povezanost između polimorfizma gena CXCR1 i rizika od endometritisa u krava holštajnske pasmine. Vet. arhiv 90, 557-563, 2020.
\end{abstract}

\title{
SAŽETAK
}

Endometritis je reproduktivna bolest koja može poremetiti poslijeporođajno zdravlje maternice u goveda, stoga je važna identifikacija genotipova otpornih na tu bolest. Cilj ovoga istraživanja bio je procijeniti povezanost između polimorfizma pojedinačnog nukleotida na genu interleukin-8 receptoru- $\alpha$ (CXCR1) i vjerojatnosti pojave endometritisa $\mathrm{u}$ holštajnskih mliječnih krava. U tu su svrhu prikupljeni uzorci krvi mliječnih krava multipara $\mathrm{s}$ kliničkim endometritisom $\mathrm{u}$ anamnezi $(\mathrm{n}=30)$ i zdravih krava kao kontrolne skupine $(\mathrm{n}=10)$. Iz uzoraka krvi izolirana je DNA. Genotip je određivan metodom lančane reakcije polimeraze - polimorfizmom dužine restrikcijskih fragmenata (PCR-RFLP). Rezultati upućuju na prisutnost različitih omjera polimorfizama $(\mathrm{G}>\mathrm{C})$ gena CXCR1 u krava s kliničkim endometritisom u usporedbi s kontrolnom skupinom. Statistička analiza pokazala je znakovitu korelaciju između incidencije bolesti i genotipa CXCR1 u poziciji nukleotida 956. Incidencija kliničkog endometritisa bila je povezana s genotipom CXCR1.956; krave s genotipom GC imale su veću incidenciju kliničkog endometritisa u usporedbi s kravama s genotipom GG. Općenito, rezultati pokazuju da bi polimorfizam CXCR1 mogao biti koristan biljeg za identifikaciju genotipova otpornih na endometritis u holštajnskih mliječnih krava.

Ključne riječi: polimorfizam; CXCR1; endometritis; mliječne krave 
